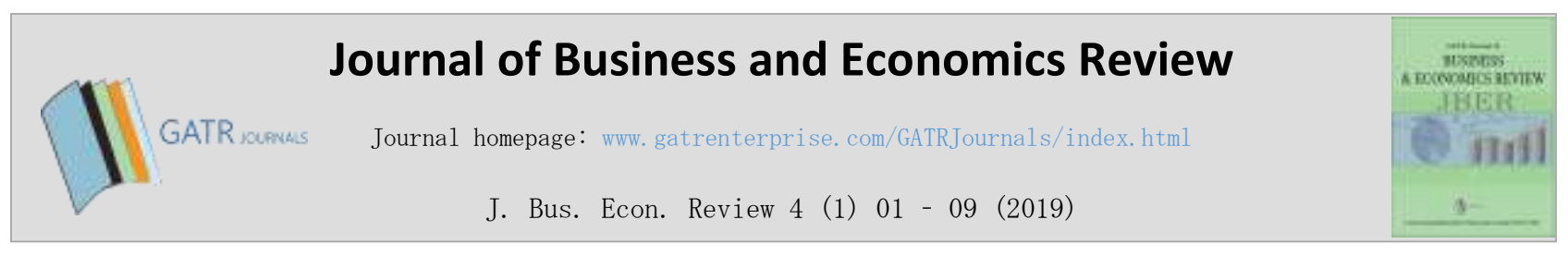

\title{
Causality of Economic Growth and Openness in ASEAN-5
}

\author{
Yarlina Yacoub $^{1}$, Nindya Lestari ${ }^{2}$ \\ ${ }^{1}$ Universitas Tanjungpura, Kalimantan Barat 78115, Indonesia \\ ${ }^{2}$ Universitas Gadjah Mada, Yogyakarta 55281, Indonesia
}

\begin{abstract}
Objective - This study aims to determine the relationship between FDI and trade and its effect on economic growth in ASEAN-5 countries using the Engel-Granger causality method.

Methodology/Technique - The study uses OLS panel regression analysis to identify the relationship between the variables in each country. The results of the Engel-Granger causality test indicate that there is a two-way relationship between economic growth and FDI, and economic growth and international trade.

Findings - When tested together through panel regression, it is concluded that the best model is a random effect method (REM) in which FDI and international trade significantly influence economic growth in the same direction. However, the relationship between FDI and international trade and its effect on economic growth in Indonesia, the Philippines and Thailand was negative, whilst in Malaysia and Singapore the relationship has a directional trend.

Novelty - To reinforce the FDI inflows, authorities should continue the progressive reduction of barriers, and increase the sophistication of quality exports to compete in the global market. This paper is the first of its kind to analyze the role of both FDI and exports in the ASEAN5 economies using panel analysis.
\end{abstract}

Type of Paper: Empirical.

JEL Classification: F02, F10, F41.

Keywords: Economic Growth; FDI; Openness; Engle-Granger Causality.

\section{Introduction}

International investment and trade are two important elements of liberalization. International investment and trade can have various effects on different industries and can have an effect on the economic growth of a country. Contributions from economic openness and investment are needed to improve economic growth. The importance of investment and international trade has remained contested until now. Empirical studies illustrate a positive relationship between investment and openness to economic growth. International investment and trade also have a positive relationship with economic growth. This means that an increase in investment and international trade will cause an increase in economic growth (Baharom et. al., 2008; Islami et. al., 2016).

\footnotetext{
* Paper Info: Revised: December 15, 2018

Accepted: March 13, 2019

* Corresponding author: Yarlina Yacoub

E-mail: yyarlina@gmail.com

Affiliation: Universitas Tanjungpura, Indonesia
} 
In addition, Habibi (2015) suggests that openness can encourage growth longer-term. Investments consisting of both domestic and foreign investment can be used to measure economic openness. In this regard, economic openness is proxied by a comparison between foreign investment and GDP in a given country. In addition, economic openness can also be determined through a comparison of the number of exports and imports to a country's GDP (World Bank, 2018).

Huchet-Bourdon and Vijil (2017) state that there is no linear relationship between export varieties, trade ratios and growth. In addition, Rasiah et. al. (2017) found that in the ASEAN-5 region, FDI and trade have a negative relationship in Thailand and no relationship in other ASEAN-5 countries. Reis (2001) also argues that FDI has a negative relationship with growth. These differences in research may be the result of differences in political policies and methods of calculation in the differing ASEAN-5 countries.

Although it is open for debate, openness and investment are believed to contribute to the value of economic growth. The existence of openness and investment in developing countries such as ASEAN-5 countries has proven to be able to increase the value of productivity and reduce unemployment and ultimately improve the welfare of workers. Thus, profits increase and increased technology transfer is achieved. Furthermore, the more technology advancements are implemented, the more efficient management will be. Therefore, both openness and investment are important.

Data from the ASEAN-5 region between 2008 and 2017 shows that ASEAN had a fairly stable growth compared to other regions, despite the 2008 financial crisis. Unlike Singapore, which experienced an increase in FDI of $95.25 \%$, other countries such as Indonesia, Malaysia, Thailand and the Philippines experienced a decline in FDI growth by $47.65 \%, 98.49 \%, 25.11 \%$ and $85.27 \%$ respectively in 2009 (Word Bank, 2018). On the other hand, over the last 10 years, ASEAN-5 countries have experienced an increase in FDI by $13.69 \%$ in Indonesia, 25.60\% in Malaysia, 421.56\% in Singapore, 6.29\% in Thailand, and 64.94\% in the Philippines (World Bank, 2018). The main FDI investor countries are EU-28, the United States of America and Japan (ASEAN, 2017). Meanwhile, ASEAN-5 net exports have increased $46.88 \%$ in Indonesia, $-47.56 \%$ in Malaysia, $152.19 \%$ in Singapore, $-18.68 \%$ in Thailand, and $192.51 \%$ in The Philippines over the last 10 years, with the main export destination countries for the ASEAN region being the United States, China and EU-28 (ASEAN, 2018).

ASEAN-5 is a proxy of economic power in ASEAN with a very large amount of foreign investment. The development of economic growth, investment and international trade in ASEAN-5 has experienced a significant change, which has had an important impact on the economy of each country. However, economic fluctuations show differences in the impact of openness and investment on economic growth. On the other hand, openness and investment have a significant relationship between countries, even though the relationship does not have positive values. Due to the importance of the relationship between economic openness and economic growth in a country, this study aims to identify the causal relationship between economic openness and economic growth in the ASEAN-5 region, using the Engel-granger method. Additionally, this study seeks to identify the statistical relationship between these variables using the pooled data method with the FEM or REM system. This was conducted to determine whether openness and investment in the ASEAN-5 region has an impact on increasing economic growth and vice versa.

\section{Literature Review}

This study uses panel data which is a combination of cross-sectional and time series data with a total of 50 observations from 5 ASEAN countries including Indonesia, Malaysia, Singapore, Thailand and the Philippines using a 10 year time period from 2008 to 2017. The variables used in this study include GDP per capita growth, a comparison of investment with GDP and a comparison of the amount of exports and imports to GDP. The data on GDP, population and FDI inflow was obtained from the World Bank whilst the export and import data was obtained from the UN-COMTRADE through the $3^{\text {rd }}$ revised SITC Code.

This study employs the Engel-granger causality, Pedroni cointegration, and panel regression with OLS. Previously, the data stationarity and cointegration test were carried out between the variables. Stationarity 
tests were carried out using the unit root test. This means that as much of the residue has been removed so that the data does not show biased results. The unit root test by Levin, Lin, Chu (LLC) was used. That test shows a stationary time test with identical first order autoregressive coefficients between individuals, thereby achieving more favorable panel data. In this regard, the analysis structure of Levin, Lin, Chu (2002) uses equations by considering the basic specifications of the ADF as follows:

$$
D Y_{i t}=\alpha Y_{i t-1}+\sum_{i=1}^{p i} \beta_{i t} D Y_{i t-1}+X_{i t}^{*} \delta+\varepsilon_{i t}
$$

Where:

$D Y_{i t}=$ the difference form of $Y_{-}$it

$Y_{i t}=$ panel data

$\mathrm{Pi}=$ the amount of lag adjusted for the form of difference

$X_{i t}^{*}=$ exogenous variable in the model such as the fixed effect of the individual trend time

$\varepsilon_{i t}=$ error term

LLC (2002) has the null hypothesis as follows:

H0: panel data has unit roots assuming a common unit root

H1: Data panel has no unit root

If, statistically, the significance level has a significant value, then $\mathrm{H} 0$ is rejected with a significance level of 0.05 , which means the panel data has no unit root.

The second stage of the study involved conducting cointegration tests using the Johansen cointegration test to determine if there is cointegration between variable residues. The cointegration test shows a long-term relationship between the independent variables and the dependent variables. The cointegration test is chosen as cointegration test method for panel data. If the Pedroni cointegration test shows the Phillips Perron test with $\mathrm{H} 0$, there is no cointegration within the following formula:

$$
\gamma^{\wedge} N, T^{-1}=\frac{\left[\sum_{i=1}^{N} \sum_{t=2}^{T}\left(e_{i, t-1}^{\wedge} \Delta e_{i, t-1}-\lambda \Gamma_{i}^{\wedge}\right)\right]}{\sum_{i=1}^{N} \sum_{t=2}^{T}\left(\hat{e}_{i, t-1}^{\wedge}\right)}
$$

Where:

$\mathrm{N}=$ cross section data

$\mathrm{T}=$ time series data

Eit-1 = error term from the model

$\wedge_{\mathrm{i}}=$ scale adjustment on the correlation matrix

The third stage involved the calculation of Engel-granger causality. The Engel-Granger causality formula in this study is as follows: 
$G D P_{-} P O P_{i t}=a_{0}+\sum_{i=1}^{m} a_{i} G D P_{-} P O P_{t-1}+\sum_{j=1}^{n} b j I N V E S T_{-} R A T I O_{t-j} \sum_{k=1}^{o} c_{k} T R A D E_{-} R A T I O_{t-k}+\varepsilon_{i t}$

$I N V E S T_{-} R A T I O_{i t}=d_{0}+\sum_{i=1}^{m} d_{i} I N V E S T \_R A T I O_{t-1}+\sum_{j=1}^{n} e j G D P P_{-} P P_{t-j} \sum_{k=1}^{o} f_{k} T R A D E_{-} R A T I O_{t-k}+\varepsilon_{i t}$

TRADE_RATIO $i t=r_{0}+\sum_{i=1}^{m} r_{i} T R A D E_{-} R A T I O_{t-1}+\sum_{j=1}^{n} S j G D P_{-} P O P_{t-j} \sum_{k=1}^{o}$ tINVEST_RATIO $_{t-k}+\varepsilon_{i t}$

Where:

GDP_POP $=$ economic growth

INVEST_RATIO = ratio FDI inflow to GDP

TRADE RATIO = ratio export and import to GDP

$\mathrm{i}=$ location

$\mathrm{t}=$ time

This research was also inspired by the research of Huchet-Bourdon et. al. (2017) which shows:

$\ln \left(\frac{G D P}{p o p}\right)=\alpha \ln \left(\frac{G D P}{p o p}\right)_{t-1}+\beta_{1}$ education $_{i, t-1}+\beta_{3} \ln \left(\frac{I}{G D P}\right)_{i, t}+\beta_{4}\left(\frac{x}{G D P}\right)_{i, t}+\beta_{5}\left(\right.$ variety $_{i, t}+\beta_{6}\left(\frac{X}{G D P}\right)_{i, t}$
$\left(\right.$ variety $_{i, t}+\mu_{1}+\gamma_{1}+V_{i, t}$

Where:

$\ln \left(\frac{G D P}{p o p}\right)=$ the economic growth of a country

$\ln \left(\frac{G D P}{p o p}\right)_{t-1}=$ economic growth in the previous year

education $_{i, t-1}=$ the level of education completed in the previous period

$\ln \left(\frac{I}{G D P}\right)_{i, t}$ is $=$ the ratio of FDI to the value of GDP

$\left(\frac{X}{G D P}\right)_{i, t}=$ comparison of export value to GDP

$(\text { variety })_{i, t}=$ the export of variety index

$\left(\frac{x}{G D P}\right)_{i, t} *\left(\right.$ variety $_{i, t}=$ the impact of exports on the export of variety index

The model includes time-specific effects ( $\mathrm{t} \gamma$ ) accounting for period-specific effects such as productivity changes that are common to all countries or the global effect of the appreciation of the US dollar and country-specific fixed-effects ( $\mathrm{i} \mu$ ) that take into account country-specific features that are constant in time, such as geography, and an error term (i t , v). 
This study uses a simpler model with the following equation:

$$
\ln \left(\frac{G D P}{p o p}\right)_{t, 1}=\alpha+\beta_{1}\left(\frac{I}{G D P}\right)_{t, i}+\beta_{2}\left(\frac{X+M}{G D P}\right)_{t, 1}+\mu_{1}
$$

Where:

$\ln \left(\frac{G D P}{p o p}\right)_{t, 1}=$ economic growth

$\beta_{1}\left(\frac{I}{G D P}\right)_{t, i}=$ the ratio of FDI to GDP

$\beta_{2}\left(\frac{X+M}{G D P}\right)_{t, 1}=$ openness which is proxied through the ratio of the number of exports and imports to GDP

$\alpha=\mathrm{a}$ constant value

$\mu_{1}=$ the error term value.

This study also uses a panel data regression to estimate economic growth, FDI ratio, and trade ratio through random effects. After conducting a stationarity and cointegration test, the study was continued with the process of panel regression to estimate economic growth, FDI ratio, and trade ratio with a random effect approach.

\section{Results and Discussion}

In the stationarity test, a significance level of 0.05 was used; if the unit root probability value is more than 0.05 , then $\mathrm{H} 0$ is rejected (Levin et. al., 2002). The stationarity test results show that all variables are stationary at level $\mathrm{I}(0)$, so they can all proceed to the next stage of the test. The results of the stationarity test are shown in Table 1.

Table 1. Unit Root Test

\begin{tabular}{|c|c|c|c|c|}
\hline Variable & Unit Root test & $\begin{array}{c}\text { Include in Test } \\
\text { Equation }\end{array}$ & Statistic & Prob \\
\hline GDP_POP & Level & Intercept & -4.814653 & $0.00000^{*}$ \\
\hline INVEST_GDP & Level & Intercept & -4.861720 & $0.00000^{*}$ \\
\hline TRADE_RATIO & Level & Intercept & -3.53654 & $0.00020^{*}$ \\
\hline
\end{tabular}

significant at 0.05

All variables were stationary at level $\mathrm{I}(0)$ and the next step was to identify the optimal lag length. All methods shown the optimum lag in fifth lags. Hence, we continued to identify the cointegration of Pedroni which generated the cointegration results indicating that $\mathrm{HO}$ is accepted, meaning that there is no cointegration between the variables.

The results of the Engel-Granger causality test indicate a two-way relationship between economic growth and FDI and economic growth and international trade. There is also a two-way relationship between FDI and 
international trade. Likewise, there is a two-way relationship between international trade and economic growth. This shows that in the ASEAN-5 region, the macro variable indicators have a strong association, although in the long term there is no relationship between variables.

Table 2. Optimum Lag Length

\begin{tabular}{|c|c|c|c|c|c|c|}
\hline Lag & LogL & LR & FPE & AIC & SC & HQ \\
\hline 0 & -212.0614696 & NA & 5951.595 & 17.20492 & 17.35118 & 17.24549 \\
\hline 1 & -83.92977552 & 215.2612 & 0.435644 & 7.674382 & 8.259442 & 7.836653 \\
\hline 2 & -80.32179016 & 5.195499 & 0.696425 & 8.105743 & 9.129599 & 8.389717 \\
\hline 3 & -58.37796447 & 26.33259 & 0.272123 & 7.070237 & 8.532888 & 7.475914 \\
\hline 4 & -41.14956156 & 16.53927 & 0.171422 & 6.411965 & 8.313411 & 6.939345 \\
\hline 5 & -15.85114311 & $18.21486^{*}$ & $0.067441^{*}$ & $5.108091^{*}$ & $7.448333^{*}$ & $5.757175^{*}$ \\
\hline
\end{tabular}

* indicates lag order selected by the criterion

Table 3. Cointegration of Pedroni

\begin{tabular}{|c|c|c|c|c|c|}
\hline & Stat & Prob & Stat & Prob & \\
\hline Panel v-stat & 0.324378 & 0.3728 & -0.44335 & 0.6712 & H0 accepted \\
\hline Panel rho-stat & 0.923778 & 0.8222 & 1.114166 & 0.8674 & H0 accepted \\
\hline Panel PP-stat & 0.216333 & 0.5856 & 0.055841 & 0.5223 & H0 accepted \\
\hline Group rho-stat & 2.013145 & 0.9780 & & H0 accepted \\
\cline { 1 - 4 } Group PP-stat & 0.228170 & 0.5902 & & H0 accepted \\
\hline
\end{tabular}

The results of the Engle-Granger causality test are as follows:

Table 4. Engle-Granger Causality

\begin{tabular}{|c|c|c|c|}
\hline Null Hypothesis & F-Statistic & Prob & \\
\hline INVEST_RATIO does not Granger Cause LOG(GDP_POP) & 0.9558006 & 0.476586 & H0 accepted \\
\hline LOG(GDP_POP) does not Granger Cause INVEST_RATIO & 0.5815712 & 0.713851 & H0 accepted \\
\hline TRADE_RATIO does not Granger Cause LOG(GDP_POP) & 0.8443127 & 0.540607 & H0 accepted \\
\hline LOG(GDP_POP) does not Granger Cause TRADE_RATIO & 1.2259205 & 0.348006 & H0 accepted \\
\hline TRADE_RATIO does not Granger Cause INVEST_RATIO & 2.9144165 & 0.052302 & H0 accepted \\
\hline INVEST_RATIO does not Granger Cause TRADE_RATIO & 1.6385691 & 0.214136 & H0 accepted \\
\hline
\end{tabular}

For the OLS model panel data regression, based on the Hausman test value, the best model is a random effect model in which FDI and international trade significantly influence economic growth. However, in 
Indonesia, the Philippines and Thailand, there is a negative relationship between FDI and international trade in economic growth, while Malaysia and Thailand show a directional trend towards the relationship.

The existence of a positive relationship between the independent variables and the dependent variable in Malaysia and Singapore indicates that economic openness can trigger economic growth in these countries. That is because the investment policies and economic openness in both countries are more effective than the other countries in the ASEAN-5 region. An investment environment that makes companies profit maximally can also positively effect FDI and its impact on economic growth. Further, the positive relationship between those variables in Malaysia and Singapore contribute to rapid economic growth, and rapid economic growth attracts investment and increases economic openness. Thus, those two countries must maintain the stability of their country, particularly in times of crisis.

Table 5. Random Effect Model (REM) Test Results

Dependent Variable: LOG(GDP_POP)

\begin{tabular}{|c|c|c|c|c|}
\hline Variable & Coefficient & Std. Error & t-Statistic & Prob. \\
\hline $\mathrm{C}$ & 7.965852 & 0.150844 & 52.80842 & 0.000000 \\
\hline INVEST_RATIO? & 6.132149 & 0.741548 & 8.269394 & 0.000000 \\
\hline TRADE_RATIO? & 0.500575 & 0.084545 & 5.920838 & 0.000000 \\
\hline \multicolumn{2}{|c|}{ Random Effects (Cross) } & & & \\
\hline INDONESIA--C & -0.19746 & & & \\
\hline MALAYSIA--C & 0.31459 & & & \\
\hline PHILIPPINES--C & -0.47235 & & & \\
\hline SINGAPORE--C & 0.39646 & & & \\
\hline THAILAND--C & -0.04125 & & & \\
\hline R-squared & 0.542763 & & & \\
\hline Adjusted R-squared & 0.523306 & & & \\
\hline F-statistic & 27.89565 & & & \\
\hline Prob(F-statistic) & 0.000000 & & & \\
\hline
\end{tabular}

On the other hand, the negative relationship between the independent variables and the dependent variable in Indonesia, Philippines and Thailand shows that economic trade in those countries does not yield productivity. Openness was not a trigger for economic growth in these countries. This can also be caused by 
the growth of these countries which is affected by other variables such as consumption and government expenditure which are not included in the calculation model. In addition, it may also be caused by industries that are too attractive and use too many inputs that turn off local industries. This causes changes in the local market and can kill local economic institutions. This also reflects less efficient production in Indonesia, the Philippines and Thailand. The high input costs yield less efficient productivity. Hence, investment and economic openness do not lead to high management efficiency in these three countries. These notions confirm the arguments put forward by Sachs and Warner (2001) and Khaliq and Noy (2014). Another thing that must be considered is domestic stability. The flow of funds will not penetrate a country if the country experiences a lot of turmoil. Thus, it is necessary for these three ASEAN countries to make various efforts to create an friendlier investment climate.

\section{Conclusion}

The relationship between openness and investment towards economic growth in the ASEAN-5 region has a positive and significant relationship as well as a strong two-way relationship. Only Malaysia and Singapore have a positive relationship. Conversely, the relationship between openness and investment towards economic growth in Indonesia, the Philippines and Thailand is negative. This has caused Malaysia and Singapore to maintain the value of their investments, particularly in times of crisis. Therefore, Indonesia, the Philippines and Thailand must be more efficient and try to maintain the stability of their country in order to create a good investment climate. It is expected that this research can shed new light on the economic situation in ASEAN-5 countries which can inform future research. Further research may wish to delve deeper into the impact of economic openness and investment on economic growth, particularly when examined together with other macro variables.

\section{References}

ASEAN. (2017) ASEAN Statistical YearBook 2016/2017. Available at www.asean.org/storage/2018/01/ASYB_2017_rev.pdf.

Baharom, A. H., Habibullah, M. S. and Faizal, R. C. R. (2008) The Relationship Between Trade Openness, Foreign Direct Investment and Growth: Case of Malaysia. MPRA Paper 11928, University Library of Munich, Germany.

Carkovic, M. and R Levine. (2005) Does Foreign Direct Investment Accelerate.

Economic Growth? In: Moran, T. H., E. M. Graham and M. Blomström. Does Foreign Direct Investment Promote Development? Institute of International Economics, Washington DC.

Chowdhury, Abdur and Mavrotas, George (2005) FDI and Growth: A Causal Relationship. Research Paper No. 2005/25. UNU-Wider. Geneva.

Dollar, D. and Kraay, A. (2001) Trade, Growth, and Poverty. World Bank Policy Research Working Paper No. 2615. Development Research Group, The World Bank.

Frankel, J. A and Romer, D. H. (1999) Does Trade Cause Growth? American Economic Review, 89(3) pp. $379-399$.

Fenira, M. (2011) Trade Openness And Growth In Developıng Countries: An Analysıs of The Relatıonshıp After Comparıng Trade Indicators Asian Economic and Financial Review 5(3), pp. 468-482.

Huchet-Bourdon, C. L. and Vijil, M (2018) The Relationship Between Trade Openness and Economic Growth: Some New Insights on the Openness Measurement Issue. The World Economy, 41(1), pp. 59-76.

Islami, X., Mulolli, E. and Skenderi, N (2016) Relationship Between FD Inflow and Economic Growth in Kosovo. European Journal of Economic and Business Studies, 1.

Jecheche, P. (2011) Investment and Growth Relationship: An Empirical Assessment in Zimbabwe. Journal of International Business and Cultural Studies.

Levin, A., Lin, C. F. and Chu, C. S. J. (2002) Unit Root Tests in Panel Data: Asymptotic and Finite-Sample Properties. Journal of Econometrics, 108, pp. 1-24.

Mun, H. W., Lin, K. T. and Man. Y. K. (2008) FDI and Economic Growth Relationship: An Empirical Study on Malaysia. International Business Research, 1(2). Malaysia. 
Rasiah, R., Asirvatham, J. and Ibrahim, M. A. (2017) Foreign Direct Investment, GDP Growth, and Trade Liberalization: Evidence from Pioneering ASEAN member. Journal of Economic Cooperation and Development, 38, 1, pp. 97-126.

Reis, A., (2001) On the Welfare Effects of Foreign Investment. Journal of International Economics 54, 411-427.

Sachs, J. D. and Warner, A. M. (2001) The Curse of Natural Resources. European Economic Review 45, 827-38.

Simionescu, M. (2016) The Relationship Between Economic Growth and Foreign Direct Investment During the Economic Crisis in the European Union. doi: 10.18045/zbefri.2016.1.187.

Uncomtrade (2018) Export-Import Data. Available at https://comtrade.un.org/data/.

World Bank. (2018) Foreign Direct Investment, GDP Constant, and Population 1990-2017. Available at https://data.worldbank.org/indicator/NY.GDP.MKTP.KD. 